Article

\title{
Synthesis and Biological Evaluation of Ginsenoside Compound K Derivatives as a Novel Class of LXR $\alpha$ Activator
}

\author{
Yan Huang ${ }^{1,+}$, Hongmei Liu ${ }^{1,+}$, Yingxian Zhang ${ }^{1}$, Jin $\mathrm{Li}^{1}$, Chenping Wang ${ }^{1}$, Li Zhou ${ }^{2}$, Yi Jia ${ }^{1, *}$ \\ and Xiaohui $\mathrm{Li}^{1 \text {,* }}$ \\ 1 Institute of Materia Medica and Department of Pharmaceutics, College of Pharmacy, \\ Third Military Medical University, Shapingba, Chongqing 400038, China; huangyanoo8@126.com (Y.H.); \\ hongmeiliu0819@126.com (H.L.);15095839731@163.com (Y.Z.); ioulj@tmmu.edu.cn (J.L.); \\ wangchenping.0219@aliyun.com (C.W.) \\ 2 Department of Pharmacy, Xinqiao Hospital \& The Second Affiliated Hospital, \\ Third Military Medical University, Shapingba, Chongqing 400037, China; zhouli1007@126.com \\ * Correspondence: jy@tmmu.edu.cn (Y.J.); xhl@tmmu.edu.cn (X.L.); Tel.: +86-23-6875-2368 (Y.J. \& X.L.); \\ Fax: +86-23-6875-3397 (Y.J. \& X.L.) \\ + These authors contributed equally to this work.
}

Received: 25 June 2017; Accepted: 18 July 2017; Published: 24 July 2017

\begin{abstract}
Compound $\mathrm{K}$ is one of the active metabolites of Panaxnotoginseng saponins, which could attenuate the formation of atherosclerosis in mice modelsvia activating $\operatorname{LXR} \alpha$. We synthesized and evaluated a series of ginsenoside compound $\mathrm{K}$ derivatives modified with short chain fatty acids. All of the structures of this class of ginsenoside compound $\mathrm{K}$ derivative exhibited comparable or better biological activity than ginsenoside compound K. Especially structure $\mathbf{1}$ exhibited the best potency (cholesteryl ester content: $41.51 \%$; expression of ABCA1 mRNA: 319\%) and low cytotoxicity.
\end{abstract}

Keywords: atherosclerosis; LXR $\alpha$; ginsenoside compound K; derivatives; reverse cholesterol transport

\section{Introduction}

Atherosclerosis is a fundamental pathological process for some severe cardiovascular diseases, including stroke, coronary artery disease, and peripheral vascular disease, and contributes to one-fifth of all deaths in the world [1]. Generally practiced pharmacologic therapies for atherosclerosis, such as statins and fibrates, are targeted for down-regulation of cholesterol and/or triglyceride levels. Despite these lipid-lowering treatments being used for decades, serious cardiovascular diseases induced by atherosclerosis are still the leading cause of death in the developed world [2]. Therefore, further development of effective therapeutic approaches is desirable.

Our previous results have showed that Panaxnotoginseng saponins exhibit significant athero-protective effects, and the mechanism was associated with $\operatorname{LXR} \alpha$ activation [3,4]. LXR $\alpha$ is a nuclear receptor protein and plays an important role in the regulation of cholesterol homeostasis and inflammation. LXR $\alpha$ regulates the reverse cholesterol transport process through the expression of down-stream proteins, such as ABCA1 and ABCG1. Thus, LXR $\alpha$ is considered a potential target for atherosclerosis therapy [5]. Ginsenoside compound $\mathrm{K}$ is one of the active metabolites of Panaxnotoginseng saponins [6]. Studies have indicated that ginsenoside compound $\mathrm{K}$ has multiple pharmacological activities, including inhibition of the proliferation of cancer $[7,8]$ and smooth muscle cells [9], activation of glucocorticoid receptors [10], anti-inflammation [11], and so on. Besides the above biological effects, our previous study has shown that ginsenoside compound $\mathrm{K}$ could attenuate the formation of atherosclerosis in mice via activating $\operatorname{LXR} \alpha$ [12], without presentation of the serious side effects caused by synthetic unspecific LXRs agonists, such as the elevation of plasma triglycerides [13] 
and liver steatosis [14]. The results indicated that ginsenoside compound $\mathrm{K}$ might have the potential to be a new effective structure for atherosclerosis therapy. However, there are still some issues with compound K pharmacological profiles, and poor water solubility is one of the major challenges [15].

Therefore, we designed and synthesized a series of ginsenoside compound $\mathrm{K}$ derivatives by introducing short chain fatty acid into the carbohydrate chain at C-3, C-18, C-32, C-33, C-34 and C-36. Since the formation of foam cells plays a key role in atherosclerosis, we detected the biological activities of the derivatives in foam cell model.

\section{Results and Discussion}

\subsection{Water Solubility Measurements}

The concentration of ginsenoside compound $\mathrm{K}$ and structure $\mathbf{1}$ in $\mathrm{ddH}_{2} \mathrm{O}$ was determined by HPLC. The results show that the mean water solubility of structure $\mathbf{1}(41.14 \mathrm{mg} / \mathrm{L})$ was significantly higher than ginsenoside compound $\mathrm{K}(1.23 \mathrm{mg} / \mathrm{L})$ (Figure 1).

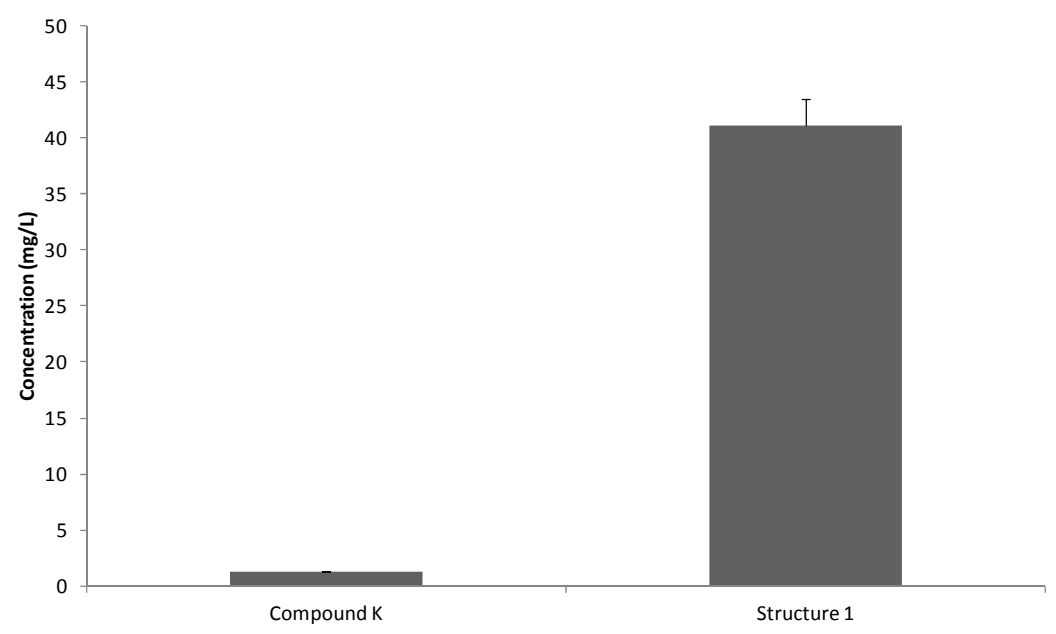

Figure 1. Water solubility measurements of structure $\mathbf{1}$ and compound K. Compound $\mathrm{K}$ and structure 1 were dissolved in $\mathrm{ddH}_{2} \mathrm{O}$ and determined by HPLC. Data were presented as mean $\pm \operatorname{SEM}(n=3)$.

\subsection{Inhibition of the Formation of Foam Cells}

Compared with the model group (treated with a bland DMSO solution), treatments with ginsenoside compound $\mathrm{K}$ and ginsenoside compound $\mathrm{K}$ derivatives $(10,30 \mu \mathrm{M})$ caused a significant decrease in lipid deposition which was red stained by Oil Red $\mathrm{O}$ in macrophage-derived foam cells (Figure 2A), consistent with the results of the quantity measurements of cellular cholesteryl ester (Figure 2B). The cholesteryl ester contents of the foam cells treated with structure $1(10 \mu \mathrm{M})$ were significantly down-regulated compared with the cells treated with ginsenoside compound $\mathrm{K}$. These results indicated that structure $\mathbf{1}$ presented better biological effects than ginsenoside compound $\mathrm{K}$. 


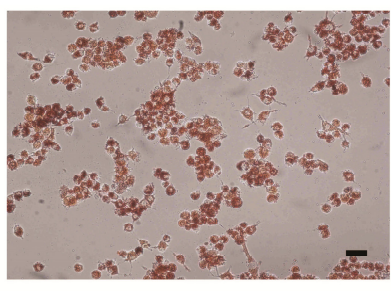

Model

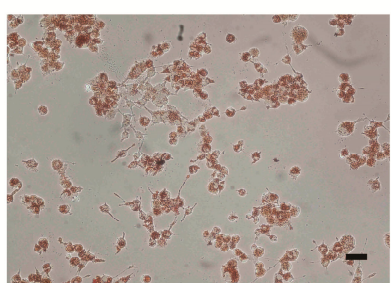

1

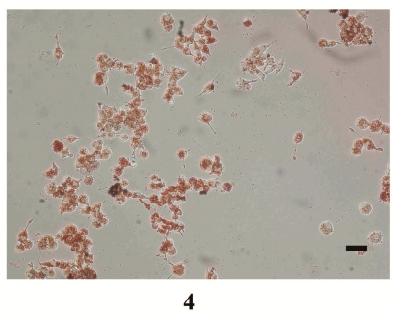

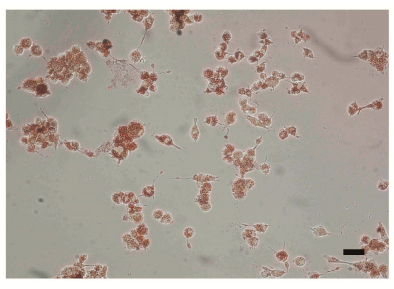

GW3965

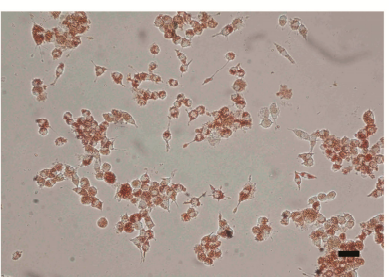

2

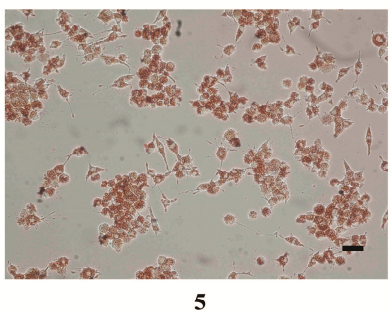

(A)

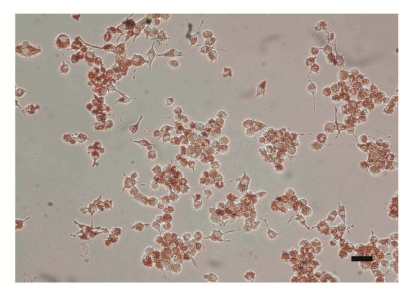

Compound K

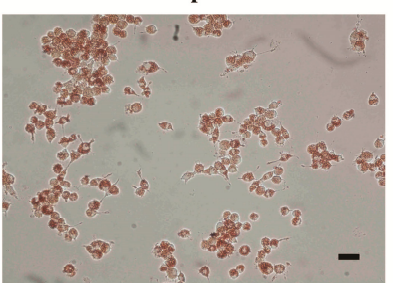

3

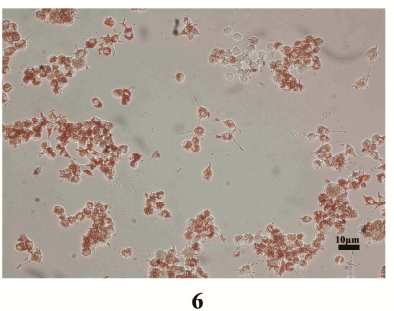

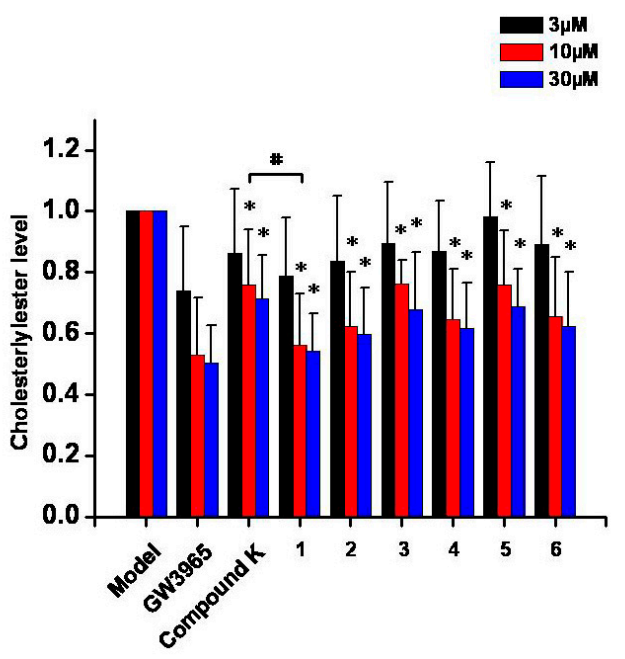

(B)

Figure 2. Effects of ginsenoside compound $\mathrm{K}$ derivatives on the formation of macrophage-derived foam cells. Foam cells were administrated by GW3965 $(10 \mu \mathrm{M})$ and ginsenoside compound K derivatives $(10 \mu \mathrm{M})$ were stained by Oil Red $\mathrm{O}$. The visible red-stained lipid drops were captured under microscope (A). Oil Red O stained cellular cholesteryl ester was extracted from administrated foam cells and detected by the optical density values (B). Data were presented as mean $\pm \operatorname{SEM}(n=8)$ and analyzed by ANOVA (analysis of variance) with Dunnett's post-hoc analysis. ${ }^{*} p<0.05$ vs. Model. $\# p<0.05$ vs. Compound K.

\subsection{Effects on ABCA1 mRNA Expression}

Increasing the mRNA expression of ABCA1, which plays a critical role in reverse cholesterol transport, can cause a reduction in the formation of foam cells. Compared with the control group, ginsenoside compound $K$, structures 1, 2 and 4 could increase the expression of ABCA1 mRNA by 
$151 \%, 319 \%, 278 \%$ and $259 \%$, respectively (Figure 3). There was statistical difference in ABCA1 mRNA expression between the structure 1 group and the compound K group.

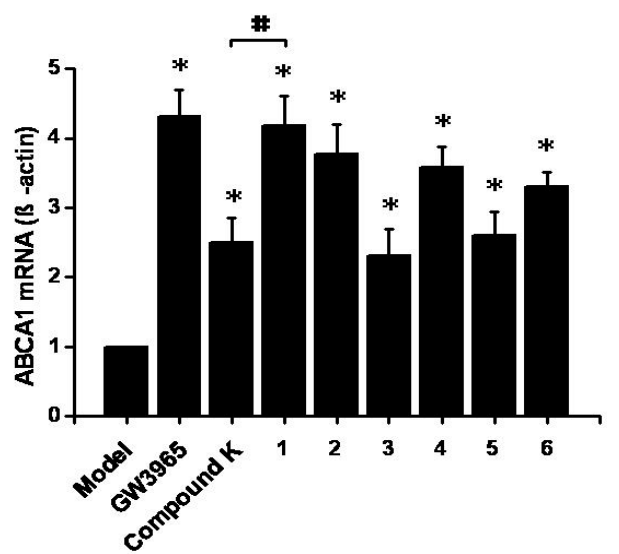

Figure 3. Effects of ginsenoside compound K derivatives on ABCA1 mRNA expression. RAW264.7 cells were treated with ginsenoside compound $\mathrm{K}$ derivatives in $10 \mu \mathrm{M}$. Expression level of ABCA1 mRNA was detected by the real-time PCR (polymerase chain reaction) method, and results were calculated relative to the control group. Data were presented as mean $\pm \operatorname{SEM}(n=5)$ and analyzed by ANOVA with Dunnett's post-hoc analysis. * $p<0.05$ vs. Control. \# $p<0.05$ vs. Compound K.

\subsection{Luciferase Reporter Assay}

The effects of ginsenoside compound K derivatives on $\mathrm{LXR} \alpha$ and $\mathrm{LXR} \beta$ activation in HEK293 cell line were detected. Ginsenoside compound K presented significant activation of LXR $\alpha$ ( 2.05 fold), consistent with our previous results. Ginsenoside compound K derivative structures 1-6, showed elevation of luciferase activity for LXR $\alpha$ at different levels (Figure 4). Among them, structure 1 showed the highest activation of $\operatorname{LXR} \alpha$ (2.67 fold), consistent with the results of the effects on the formation of foam cells and ABCA1 mRNA experiments. Ginsenoside compound K and the derivatives did not show significant activation of LXR $\beta$.

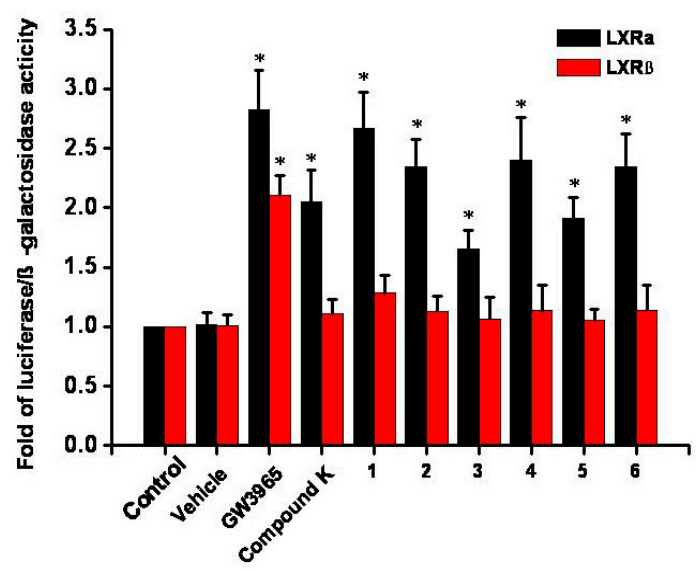

Figure 4. Effects of ginsenoside compound $\mathrm{K}$ derivatives on $\mathrm{LXR} \alpha$ and $\mathrm{LXR} \beta$ activation in HEK293. The results were showed as relative luciferase activity (fold difference compared to the control group). Ginsenoside compound $\mathrm{K}$ derivatives $(10 \mu \mathrm{M})$ showed an elevation of luciferase activity for LXR $\alpha$ at different levels. Among them, structure 1 showed significant activation of LXR $\alpha$. These structures did not show significant activation of luciferase activity for LXR $\beta$. Data are presented as mean $\pm \operatorname{SEM}(n=3$, each in duplicate), and analyzed by ANOVA with Dunnett's post-hoc analysis. * $p<0.05$ vs. Control. 


\subsection{Cell Toxicity}

Compared with the control group, ginsenoside compound $\mathrm{K}$ derivative structures 3 and $\mathbf{5}$ significantly decreased the survival ratios of RAW264.7 cells in 10 and $30 \mu \mathrm{M}$ (Figure 5A). Compared with control group, structure $\mathbf{1}(30 \mu \mathrm{M})$, structure $2(10$ and $30 \mu \mathrm{M})$, structure $3(10$ and $30 \mu \mathrm{M})$ and structure $5(10$ and $30 \mu \mathrm{M})$ significantly decreased the survival ratios of HUVEC (human umbilical vein endothelial cell) (Figure 5B). All the structures and ginsenoside compound K showed significant toxic effects in $100 \mu \mathrm{M}$. The results of structure 3 and 5 might present more toxic effects.

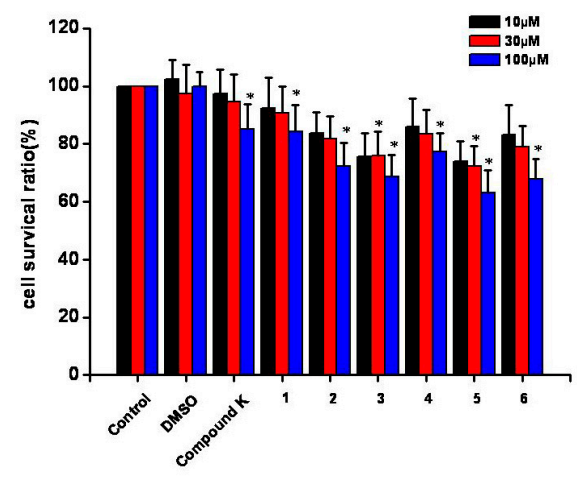

(A)

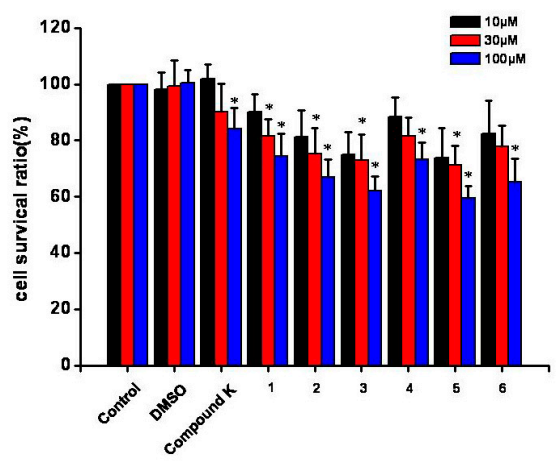

(B)

Figure 5. Cell toxicity of ginsenoside compound K derivatives. RAW264.7 (A) and HUVEC (B) cells were treated with ginsenoside compound $\mathrm{K}$ derivatives in different concentrations. Cell survival ratio was measured by the CCK-8 method, and results were calculated relative to the control group. Data were presented as mean $\pm \operatorname{SEM}(n=3)$ and analyzed by ANOVA with Dunnett's post-hoc analysis. * $p<0.05$ vs. Control.

\subsection{Compound K and Structure 1 Dock into the LXR $\alpha$}

The crystal structure for the mouse was prepared by SYBYL-X 2.0. The docking score of structure 1 (8.6) was significantly higher than the ginsenoside compound $\mathrm{K}(4.2)$. The ginsenoside compound $\mathrm{K}$ ligand occupies a proportionally large volume of the cavity space within the ligand-binding pocket of $\mathrm{LXR} \alpha$ (Figure 6A). The experimental result showed ginsenoside compound $\mathrm{K}$ and structure $\mathbf{1}$ is primarily bound to LXR $\alpha$ through hydrogen bonding via the hydroxyl group present on the molecule. A hydrogen bond was predicted between the hydroxyl group at $\mathrm{C}-36$ of compound $\mathrm{K}$ and the carboxyl group of His-417, and the hydroxyl group at $\mathrm{C}-12$ of compound $\mathrm{K}$ formed a hydrogen bond with the hydroxyl group ofThr-300 (Figure 6B). Structure 1 displays different bonding modes, the ester group at $\mathrm{C}-3$ of structure 1 formed a hydrogen bond with the amide group of Asn-223, and the carboxyl group at C-3 of structure $\mathbf{1}$ formed a hydrogen bond with the amide group of Leu314.Moreover, the acetyl group at C-34 of 1 formed a hydrogen bond with the imidazole nitrogen of His-419 (Figure 6C).

\subsection{Discussion}

Oil Red $\mathrm{O}$ staining experiment results indicated that the ginsenoside compound $\mathrm{K}$ derivatives caused a significant decrease in lipid deposition in the macrophage-derived foam cells. Ginsenoside compound $\mathrm{K}$ and the derivatives showed an elevation of luciferase activity for LXR $\alpha$ at different levels and did not show significant activation of LXR $\beta$. Ginsenoside compound K and structure $\mathbf{1}$ did not adopt a uniform binding way, as did other steroid agonists $[16,17]$. Hence, the ligand docking study has provided insight into the binding affinity to $L X R \alpha$ receptors. The characterization of $L X R \alpha$ as a regulator of reverse cholesterol transport is well known. Studies show that the activation of $\mathrm{LXR} \alpha$ can up-regulate multiple downstream genes, including ABCA1 and ABCG1 in macrophages as efflux transporters [18], and ABCG5 and ABCG8 in enterocytes as excretion transporters [19]. In the present research into macrophages, we used ABCA1 mRNA levels as the marker of the activation 
degree of LXR $\alpha$. The results of cell models showed structure $\mathbf{1}$ presented the best bioactivity, highest ABCA1 mRNA level, and lowest cellular cholesterol ester level among the compound K derivatives. Our results presented here suggest that all of the structures unambiguously enhanced the activation of $\mathrm{LXR} \alpha$, but the activation potency gradually declines along with the growth of the fatty acid carbon chain, and, quite the opposite, that the cytotoxicity of structures grows gradually following the growth of the fatty acid carbon chain. Among all tested structures, structure $\mathbf{1}$ exhibited the best potency and lower cell toxicity.

A

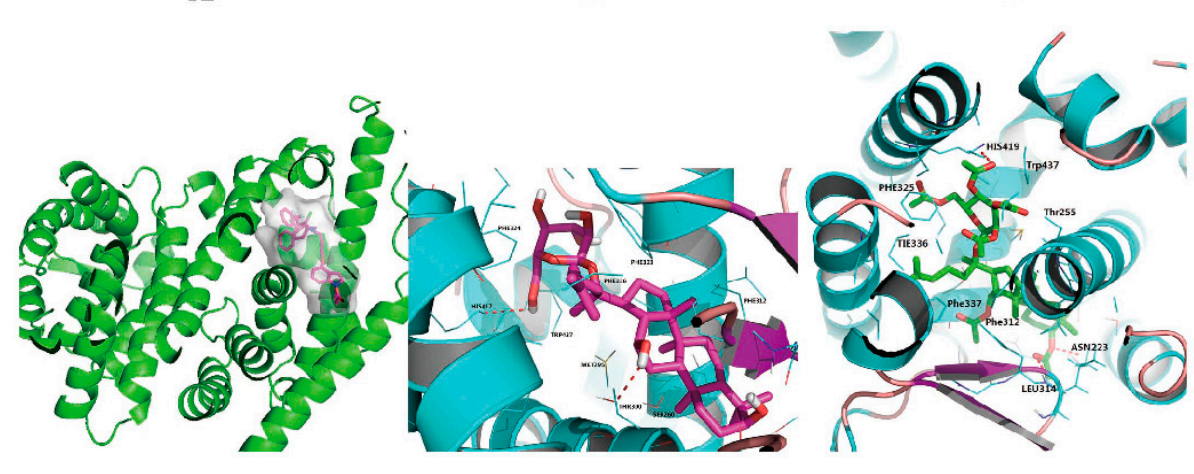

Figure 6. (A) The ginsenoside compound $\mathrm{K}$ ligand occupies a proportionally large volume of the cavity space within the ligand-binding pocket of $\operatorname{LXR} \alpha$; (B) A hydrogen bond was predicted between the hydroxyl group at C-36 of compound $\mathrm{K}$ and the carboxyl group of His-417, and the hydroxyl group at $\mathrm{C}-12$ of ginsenoside compound $\mathrm{K}$ formed a hydrogen bond with the hydroxyl group ofThr-300; (C) the ester group at $\mathrm{C}-3$ of ginsenoside compound $\mathrm{K}$ derivatives structure $\mathbf{1}$ formed a hydrogen bond with the amide group of Asn223, and the carboxyl group at C-3 of $\mathbf{1}$ formed a hydrogen bond with the amide group ofLeu314.Moreover, the acetyl group at C-34 of structure $\mathbf{1}$ formed a hydrogen bond with the imidazole nitrogen of His-419.

\section{Design and Syntheses}

Our previous results have showed that compound $\mathrm{K}$ could attenuate the formation of atherosclerosis in mice via activating $\operatorname{LXR} \alpha$. On the basis of previous literature, it can be seen that short-chain, fatty-acid-modified molecules markedly increase water solubility $[20,21]$ and enhance the cellular uptake of molecules [22,23]. An attractive feature of these structures' decomposition of secondary metabolites is the low toxicity natural by products [24]. Therefore, we designed various short-chain, fatty-acid-modified ginsenoside compound K analogues (Scheme 1). Preliminary results showed that structure 1 exhibited better efficacy for the activation of ABCA1 mRNA than ginsenoside compound K. Thus, we synthesized a series of short-chain, fatty-acid-modified ginsenoside compound K derivatives (2-6) for further exploration of the structure-activity relationships. 


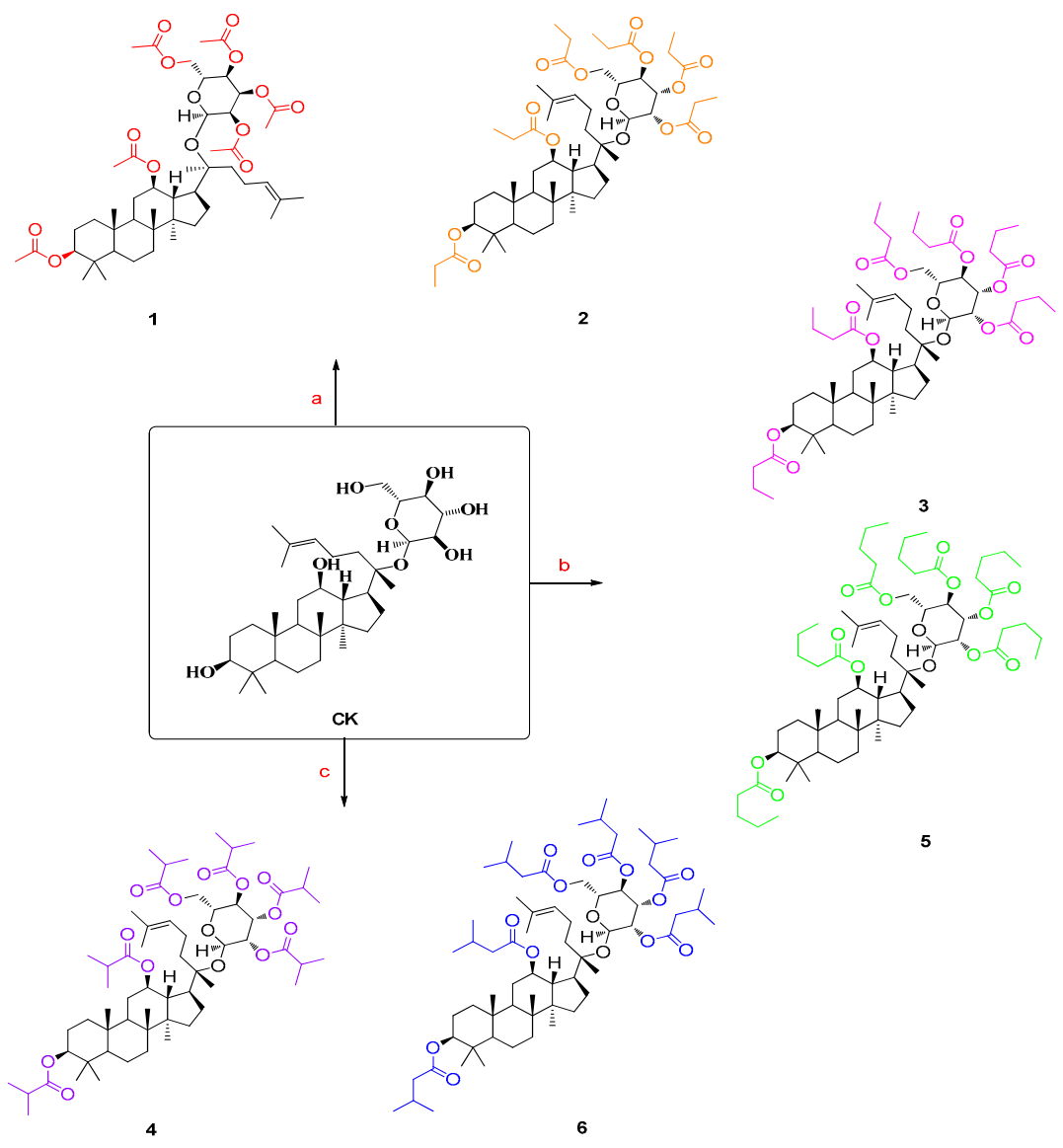

Scheme 1. Synthesis of ginsenoside compound K derivatives structures 1-6. Reagents and conditions (a) short chain fatty anhydride-pyridine, $60^{\circ} \mathrm{C}, 24 \mathrm{~h}$; (b) short-chain, fatty anhydride, pyridine and DMAP (4-dimethylaminopyridine), $80^{\circ} \mathrm{C}, 24 \mathrm{~h}$; (c) short-chain fatty anhydride, pyridine and DMAP, $90{ }^{\circ} \mathrm{C}, 24 \mathrm{~h}$.

\section{Experimental}

\subsection{General}

All the starting materials were of reagent grade. The solvents used for the isolation and purification of the structures were obtained from J\&K Scientific LTD (Beijing, China). All reactions were carried out in oven-dried glassware under an argon atmosphere unless otherwise noted. All yields reported refer to the yields of the isolated structures. RAW264.7, HUVEC and HEK293 cells were obtained from the Type Culture Collection of the Chinese Academy of Sciences (Shanghai, China). CCK-8 reagents were obtained from Dojindo (Kumamoto, Japan), Oil Red O were obtained from Sigma-aldrich (St. Louis, USA), Total RNA Kit was obtained from Tiangen (Beijing, China), PrimeScript ${ }^{\mathrm{TM}}$ RT reagent Kit and SYBR ${ }^{\circledR}$ Premix Ex Taq ${ }^{\mathrm{TM}}$ II were obtained from TaKaRa (Tokyo, Japan), REALPLEX were obtained from Eppendorf (Hamburg, Germany). ${ }^{1} \mathrm{H}-\mathrm{NMR}$ and ${ }^{13} \mathrm{C}-\mathrm{NMR}$ spectra were recorded using a Varian Inova-600 spectrometer $(600 \mathrm{MHz})$. High-resolution mass spectra were obtained with a MALDI-TOF (MALDI-7090, SHIMADZU) mass spectrometer. Silica gel TLC plates (Qing Dao Marine Chemical Factory, Qingdao, China) were used to monitor the progression of the reactions. Flash column chromatography was performed using silica gel (200-400 mesh size, Qing Dao Marine Chemical Factory, Qingdao, China). 


\subsection{General Synthetic Procedure for Structures 1-6 [25-28]}

\subsubsection{Ginsenoside Compound K Derivative 1 (Structure 1)}

A solution of ginsenoside compound $\mathrm{K}(0.1 \mathrm{~g}, 1.6 \mu \mathrm{mol})$ in pyridine $(1 \mathrm{~mL})$ was mixed with Ac2O $(1 \mathrm{~mL})$, and the mixture was stirred at $60{ }^{\circ} \mathrm{C}$ for $24 \mathrm{~h}$. Then the mixture was added to ddH $\mathrm{H}_{2} \mathrm{O}$ $(500 \mathrm{~mL})$ and the product was isolated by extraction with dichloromethane $(300 \mathrm{~mL})$. The organic phase was washed with lye, brine, dried over anhydrous sodium sulfate, filtered, then Silica gel was added and concentrated under vacuum. After the evaporation of excess reagent, the residue was subjected to column chromatography on silica gel using PE/EtOAc $(5 / 1, v / v)$ to yield white powder (0.12 g, $13.7 \mu \mathrm{mol}, 85 \%)$.

${ }^{1} \mathrm{H}-\mathrm{NMR}\left(600 \mathrm{MHz}, \mathrm{CDCl}_{3}\right) \delta 5.17(\mathrm{t}, J=9.5 \mathrm{~Hz}, 1 \mathrm{H}), 5.02-4.96(\mathrm{~m}, 2 \mathrm{H}), 4.93-4.88(\mathrm{~m}, 1 \mathrm{H})$, $4.81(\mathrm{td}, J=10.9,5.1 \mathrm{~Hz}, 1 \mathrm{H}), 4.65(\mathrm{~d}, J=7.9 \mathrm{~Hz}, 1 \mathrm{H}), 4.46(\mathrm{dd}, J=11.0,4.5 \mathrm{~Hz}, 1 \mathrm{H}), 4.14-4.06(\mathrm{~m}, 2 \mathrm{H})$, 3.66-3.61 (m, 1H), 2.09-1.99 (m, 7H), 1.97 (d, J = 8.9 Hz, 3H) (Supplementary Figure S1).

${ }^{13} \mathrm{C}-\mathrm{NMR}\left(151 \mathrm{MHz}, \mathrm{CDCl}_{3}\right) \delta 175.36,174.99,174.80,174.23,173.86,173.39,134.73,128.49,98.22,86.86$, $84.77,79.02,77.19,75.98,75.03,72.66,66.13,59.68,56.60,53.73,52.36,52.07,49.27,43.33,42.31,41.43$, $40.66,38.07,35.11,32.61,30.93,29.95,28.40,27.11,26.50,25.11,24.57,23.64,23.52,23.24,23.09,23.07$, 21.76, 21.04, 20.38, 19.42, 19.20, 18.66 (Supplementary Figure S7).

MALDI-TOF-MS $m / z$ calcd. for $\mathrm{C}_{48} \mathrm{H}_{74} \mathrm{O}_{14}[\mathrm{M}+\mathrm{Na}]^{+}$897.51, found 897.674.

\subsubsection{Ginsenoside Compound K Derivative 2 (Structure 2)}

A solution of ginsenoside compound $\mathrm{K}(0.1 \mathrm{~g}, 1.6 \mu \mathrm{mol})$ in pyridine $(1 \mathrm{~mL})$ was mixed with propionic anhydride $(1 \mathrm{~mL})$, and the mixture was stirred at $60{ }^{\circ} \mathrm{C}$ for $24 \mathrm{~h}$. Then the mixture was added to $\mathrm{ddH}_{2} \mathrm{O}(500 \mathrm{~mL})$ and the product was isolated by extraction with dichloromethane $(300 \mathrm{~mL})$. The organic phase was washed with lye, brine, dried over anhydrous sodium sulfate, filtered, and then Silica gel was added and concentrated under vacuum. After the evaporation of excess reagent, the residue was subjected to column chromatography on silica gel using PE/EtOAc $(5 / 1, v / v)$ to yield white powder $(0.13 \mathrm{~g}, 13.6 \mu \mathrm{mol}, 84 \%)$.

${ }^{1} \mathrm{H}-\mathrm{NMR}\left(600 \mathrm{MHz}, \mathrm{CDCl}_{3}\right) \delta 5.20(\mathrm{t}, J=9.5 \mathrm{~Hz}, 1 \mathrm{H}), 5.00(\mathrm{dd}, J=18.6,8.9 \mathrm{~Hz}, 2 \mathrm{H}), 4.94(\mathrm{dd}, J=9.6$, $8.0 \mathrm{~Hz}, 1 \mathrm{H}), 4.83(\mathrm{td}, J=10.9,5.0 \mathrm{~Hz}, 1 \mathrm{H}), 4.65(\mathrm{~d}, J=7.9 \mathrm{~Hz}, 1 \mathrm{H}), 4.48(\mathrm{dd}, J=11.5,4.4 \mathrm{~Hz}, 1 \mathrm{H})$, 4.14-4.07 (m, 2H), 3.74-3.61 (m, 2H), 2.40-2.15 (m, 12H), 1.09 (dddd, $J=26.8,19.2,11.5,6.5 \mathrm{~Hz}, 17 \mathrm{H}$ ), $0.95(\mathrm{~s}, 3 \mathrm{H}), 0.91(\mathrm{~s}, 3 \mathrm{H}), 0.86(\mathrm{~s}, 3 \mathrm{H}), 0.83(\mathrm{~d}, J=3.1 \mathrm{~Hz}, 6 \mathrm{H})$ (Supplementary Figure S2).

${ }^{13} \mathrm{C}-\mathrm{NMR}\left(151 \mathrm{MHz}, \mathrm{CDCl}_{3}\right) \delta 174.18,174.16,173.73,173.65,172.92,172.42,131.39,124.25,109.82,94.54$, 83.01, 80.15, 74.77, 72.96, 71.66, 71.51, 68.76, 68.50, 62.37, 55.74, 53.02, 49.65, 47.21, 45.29, 39.41, 39.07, $38.35,37.87,36.88,34.32,31.73,29.03,28.11,27.99,27.90,27.41,27.38,27.35,27.24,26.30,25.58,23.47$, $22.87,22.51,21.96,18.07,17.63,16.36,15.99,15.31,9.26,9.07,9.00,8.98,8.96,8.89$ (Supplementary Figure S8).

MALDI-TOF-MS m/z calcd. for $\mathrm{C}_{54} \mathrm{H}_{86} \mathrm{O}_{14}[\mathrm{M}+\mathrm{Na}]^{+}$981.60, found 981.313.

\subsubsection{Ginsenoside Compound K Derivative 3 (Structure 3)}

A solution of ginsenoside compound $\mathrm{K}(0.1 \mathrm{~g}, 1.6 \mu \mathrm{mol})$ and DMAP $(0.01 \mathrm{~g}, 0.08 \mathrm{mmol})$ in pyridine $(1 \mathrm{~mL})$ was mixed with butyric anhydride $(1 \mathrm{~mL})$, and the mixture was stirred at $80{ }^{\circ} \mathrm{C}$ for $24 \mathrm{~h}$. Then the mixture was added to $\mathrm{ddH}_{2} \mathrm{O}(500 \mathrm{~mL})$ and the product was isolated by extraction with dichloromethane $(300 \mathrm{~mL})$. The organic phase was washed with lye, brine, dried over anhydrous sodium sulfate, filtered, then Silica gel was added and concentrated under vacuum. After the evaporation of excess reagent, the residue was subjected to column chromatography on silica gel using $\mathrm{PE} / \operatorname{EtOAc}(5 / 1, v / v)$ to yield white powder $(0.09 \mathrm{~g}, 8.6 \mu \mathrm{mol}, 55 \%)$. 
${ }^{1} \mathrm{H}-\mathrm{NMR}\left(600 \mathrm{MHz}, \mathrm{CDCl}_{3}\right) \delta 5.20(\mathrm{t}, J=9.5 \mathrm{~Hz}, 1 \mathrm{H}), 5.01(\mathrm{dd}, J=19.8,10.0 \mathrm{~Hz}, 1 \mathrm{H}), 4.94(\mathrm{dd}, J=9.6$, $8.0 \mathrm{~Hz}, 1 \mathrm{H}), 4.82(\mathrm{td}, J=10.8,4.9 \mathrm{~Hz}, 1 \mathrm{H}), 4.64(\mathrm{~d}, J=7.9 \mathrm{~Hz}, 1 \mathrm{H}), 4.48(\mathrm{dd}, J=11.2,4.6 \mathrm{~Hz}, 1 \mathrm{H})$, $4.13(\mathrm{dd}, J=12.0,2.1 \mathrm{~Hz}, 1 \mathrm{H}), 4.05(\mathrm{dd}, J=12.1,6.1 \mathrm{~Hz}, 1 \mathrm{H}), 3.65-3.59(\mathrm{~m}, 1 \mathrm{H}), 2.45-2.10(\mathrm{~m}, 12 \mathrm{H})$, $1.65-1.56(\mathrm{~m}, 18 \mathrm{H}), 1.04-0.71(\mathrm{~m}, 33 \mathrm{H})$ (Supplementary Figure S3).

${ }^{13} \mathrm{C}-\mathrm{NMR}\left(151 \mathrm{MHz}, \mathrm{CDCl}_{3}\right) \delta 173.40,173.32,172.87,172.80,172.06,171.58,131.46,124.41,94.69,83.17$, 80.27, 74.92), 72.93, 71.68, 71.53, 68.51, 62.36, 55.84, 53.11, 49.94, 47.28, 45.50, 39.49, 38.99, 38.43, 38.42, $37.89,36.94,36.81,36.72,35.95,35.86,35.80,34.40,31.84,29.08,27.95,26.41,25.68,23.58,22.94,22.10$, $18.59,18.26,18.21,18.20,18.13,18.12,18.10,17.72,16.50,16.13,15.40,13.73,13.72,13.63,13.59,13.58$, 13.58 (Supplementary Figure S9).

MALDI-TOF-MS $m / z$ calcd. for $\mathrm{C}_{60} \mathrm{H}_{98} \mathrm{O}_{14}[\mathrm{M}+\mathrm{Na}]^{+}$1065.70, found1065.425.

\subsubsection{Ginsenoside Compound K Derivative 4 (Structure 4)}

A solution of ginsenoside compound $\mathrm{K}(0.1 \mathrm{~g}, 1.6 \mu \mathrm{mol})$ and DMAP $(0.01 \mathrm{~g}, 0.08 \mathrm{mmol})$ in pyridine $(1 \mathrm{~mL})$ was mixed with isobutyric anhydride $(1 \mathrm{~mL})$, and the mixture was stirred at $90^{\circ} \mathrm{C}$ for $24 \mathrm{~h}$. Then the mixture was added to $\mathrm{ddH}_{2} \mathrm{O}(500 \mathrm{~mL})$ and the product was isolated by extraction with $300 \mathrm{~mL}$ dichloromethane $(300 \mathrm{~mL})$. The organic phase was washed with lye, brine, dried over anhydrous sodium sulfate, filtered, then Silica gel was added and concentrated under vacuum. After the evaporation of excess reagent, the residue was subjected to column chromatography on silica gel using PE/EtOAc (5/1, v/v) to yield white powder (0.06 g, $5.6 \mu \mathrm{mol}, 35 \%)$.

${ }^{1} \mathrm{H}-\mathrm{NMR}\left(600 \mathrm{MHz}, \mathrm{CDCl}_{3}\right) \delta 5.28(\mathrm{t}, J=9.5 \mathrm{~Hz}, 2 \mathrm{H}), 5.05(\mathrm{dd}, J=19.8,10.0 \mathrm{~Hz}, 1 \mathrm{H})$, $5.03(\mathrm{dd}, J=9.6,8.0 \mathrm{~Hz}, 1 \mathrm{H}), 4.97(\mathrm{td}, J=10.8,4.9 \mathrm{~Hz}, 1 \mathrm{H}), 4.46(\mathrm{~d}, J=7.9 \mathrm{~Hz}, 1 \mathrm{H}), 4.01(\mathrm{dd}, J=12.0$, $2.1 \mathrm{~Hz}, 1 \mathrm{H}), 3.67(\mathrm{dd}, J=12.1,6.1 \mathrm{~Hz}, 1 \mathrm{H}), 3.51(\mathrm{~m}, 1 \mathrm{H}), 2.61-2.35(\mathrm{~m}, 6 \mathrm{H}), 0.87-0.79(\mathrm{~m}, 36 \mathrm{H})$ (Supplementary Figure S4).

${ }^{13} \mathrm{C}-\mathrm{NMR}\left(151 \mathrm{MHz}, \mathrm{CDCl}_{3}\right)$ 8173.55, 173.48, 173.03, 172.98, 172.20, 171.71, 131.11, 124.09, 94.51, 83.13, 80.17, 74.72, 72.71, 71.65, 71.52, 68.45, 62.29, 55.74, 52.97, 49.90, 47.11, 45.44, 39.46, 38.98, 38.36, 37.85, $36.91,34.67,34.53,34.39,33.78,33.77,33.71,33.67,31.80,29.07,27.95,27.19,26.87,26.85,26.77,26.75$, 25.68, 23.56, 22.94, 22.32, 22.30, 22.29, 22.20, 22.19, 22.16, 18.12, 17.74, 16.50, 16.14, 15.40, 13.79, 13.74, 13.72, 13.60 (Supplementary Figure S10).

MALDI-TOF-MS $m / z$ calcd. for $\mathrm{C}_{60} \mathrm{H}_{98} \mathrm{O}_{14}[\mathrm{M}+\mathrm{H}]^{+}$1066.70, found 1066.522.

\subsubsection{Ginsenoside Compound K Derivative 5 (Structure 5)}

A solution of ginsenoside compound $\mathrm{K}(0.1 \mathrm{~g}, 1.6 \mu \mathrm{mol})$ and DMAP $(0.01 \mathrm{~g}, 0.08 \mathrm{mmol})$ in pyridine $(1 \mathrm{~mL})$ was mixed with valeric anhydride $(1 \mathrm{~mL})$, and the mixture was stirred at $80{ }^{\circ} \mathrm{C}$ for $24 \mathrm{~h}$. Then the mixture was added to $\mathrm{ddH}_{2} \mathrm{O}(500 \mathrm{~mL})$ and the product was isolated by extraction with dichloromethane $(300 \mathrm{~mL})$. The organic phase was washed with lye, brine, dried over anhydrous sodium sulfate, filtered, then Silica gel was added and concentrated under vacuum. After the evaporation of excess reagent, the residue was subjected to column chromatography on silica gel using $\mathrm{PE} / \mathrm{EtOAc}(5 / 1, v / v)$ to yield white powder $(0.08 \mathrm{~g}, 6.9 \mu \mathrm{mol}, 43 \%)$.

${ }^{1} \mathrm{H}-\mathrm{NMR}\left(600 \mathrm{MHz}, \mathrm{CDCl}_{3}\right) \delta 5.20(\mathrm{t}, J=9.5 \mathrm{~Hz}, 1 \mathrm{H}), 5.01(\mathrm{t}, J=9.7 \mathrm{~Hz}, 1 \mathrm{H}), 4.98(\mathrm{~s}, 1 \mathrm{H})$, $4.96-4.91(\mathrm{~m}, 1 \mathrm{H}), 4.81(\mathrm{td}, J=10.7,4.8 \mathrm{~Hz}, 1 \mathrm{H}), 4.64(\mathrm{~d}, J=7.9 \mathrm{~Hz}, 1 \mathrm{H}), 4.47(\mathrm{dd}, J=11.1,4.6 \mathrm{~Hz}, 1 \mathrm{H})$, $4.12(\mathrm{dd}, J=12.0,2.0 \mathrm{~Hz}, 1 \mathrm{H}), 4.05(\mathrm{dd}, J=12.1,6.0 \mathrm{~Hz}, 1 \mathrm{H}), 3.65-3.59(\mathrm{~m}, 1 \mathrm{H}), 2.38-2.15(\mathrm{~m}, 12 \mathrm{H})$, $1.36-1.25(\mathrm{~m}, 12 \mathrm{H}), 0.91-0.84(\mathrm{~m}, 18 \mathrm{H})$ (Supplementary Figure S5).

${ }^{13} \mathrm{C}-\mathrm{NMR}\left(151 \mathrm{MHz}, \mathrm{CDCl}_{3}\right) \delta 173.54,173.46,173.02,172.98,172.19,171.72,131.54,124.42,94.70,83.17$, 80.27, 74.93, 73.14, 71.67, 71.57, 68.56, 62.39, 55.86, 53.11, 49.96, 47.24, 45.53, 39.51, 39.01, 38.45, 37.90, $36.95,34.71,34.52,34.43,33.78,33.76,33.70,33.66,31.85,29.10,27.95,27.23,27.18,26.87,26.84,26.76$, 
$26.75,26.72,26.40,25.65,23.58,22.96,22.31,22.29,22.27,22.19,22.17,22.15,22.07,18.12,17.72,16.49$, 16.13, 15.43, 13.76, 13.76, 13.71, 13.69, 13.59, 13.58 (Supplementary Figure S11).

MALDI-TOF-MS $m / z$ calcd. for $\mathrm{C}_{66} \mathrm{H}_{110} \mathrm{O}_{14}[\mathrm{M}+\mathrm{Na}]^{+} 1149.79$, found 1149.492 .

\subsubsection{Ginsenoside Compound K Derivative 6 (Structure 6)}

A solution of ginsenoside compound $\mathrm{K}(0.1 \mathrm{~g}, 1.6 \mu \mathrm{mol})$ and DMAP $(0.01 \mathrm{~g}, 0.08 \mathrm{mmol})$ in pyridine $(1 \mathrm{~mL})$ was mixed with butyric anhydride $(1 \mathrm{~mL})$, and the mixture was stirred at $90{ }^{\circ} \mathrm{C}$ for $24 \mathrm{~h}$. Then the mixture was added to $\mathrm{ddH}_{2} \mathrm{O}(500 \mathrm{~mL})$ and the product was isolated by extraction with dichloromethane $(300 \mathrm{~mL})$. The organic phase was washed with lye, brine, dried over anhydrous sodium sulfate, filtered, then Silica gel was added and concentrated under vacuum. After the evaporation of excess reagent, the residue was subjected to column chromatography on silica gel using $\mathrm{PE} / \mathrm{EtOAc}(5 / 1, v / v)$ to yield white powder $(0.09 \mathrm{~g}, 8.0 \mu \mathrm{mol}, 50 \%)$.

${ }^{1} \mathrm{H}-\mathrm{NMR}\left(600 \mathrm{MHz}, \mathrm{CDCl}_{3}\right) \delta 5.21(\mathrm{t}, J=9.5 \mathrm{~Hz}, 1 \mathrm{H}), 5.01(\mathrm{dd}, J=19.2,9.4 \mathrm{~Hz}, 2 \mathrm{H}), 4.93(\mathrm{dd}, J=9.6$, $7.9 \mathrm{~Hz}, 1 \mathrm{H}), 4.82(\mathrm{td}, J=10.7,4.8 \mathrm{~Hz}, 1 \mathrm{H}), 4.63(\mathrm{~d}, J=7.9 \mathrm{~Hz}, 1 \mathrm{H}), 4.48(\mathrm{dd}, J=11.4,4.7 \mathrm{~Hz}, 1 \mathrm{H})$, $4.17(\mathrm{dd}, J=12.1,2.0 \mathrm{~Hz}, 1 \mathrm{H}), 4.00(\mathrm{dd}, J=12.1,6.0 \mathrm{~Hz}, 1 \mathrm{H}), 3.64-3.58(\mathrm{~m}, 1 \mathrm{H}), 2.23-1.95(\mathrm{~m}, 15 \mathrm{H})$, $1.02-0.79(\mathrm{~m}, 40 \mathrm{H})$ (Supplementary Figure S6).

${ }^{13} \mathrm{C}-\mathrm{NMR}\left(151 \mathrm{MHz}, \mathrm{CDCl}_{3}\right) \delta 172.85,172.73,172.32,172.11,171.46,170.98,131.42,124.44,94.71,83.24$, $80.29,74.90,72.75,71.69,71.48,68.55,62.31,55.85,53.11,49.99,47.29,45.53,43.99,43.98,42.98,42.95$, $39.51,38.71,38.42,37.83,36.93,34.41,31.90,29.68,29.08,27.96,26.48,25.75,25.73,25.54,25.51,25.30$, $25.15,25.04,23.60,22.96,22.57,22.48,22.44,22.42,22.41,22.40,22.40,22.39,22.38,22.37,22.36,22.33$, 22.31, 22.13, 18.18, 18.13, 17.76, 16.52, 16.12, 15.42 (Supplementary Figure S12).

MALDI-TOF-MS $m / z$ calcd. for $\mathrm{C}_{66} \mathrm{H}_{110} \mathrm{O}_{14}[\mathrm{M}+\mathrm{Na}]^{+} 1149.79$, found 1149.439 .

\subsection{Water Solubility Measurements}

$1 \mathrm{mg}$ Protopanoxadiol (PPD) was placed into a vial containing $1 \mathrm{~mL}$ of methanol, and $2 \mathrm{mg}$ of ginsenoside compound $\mathrm{K}$ or ginsenoside compound $\mathrm{K}$ derivative structure $\mathbf{1}$ was placed separately

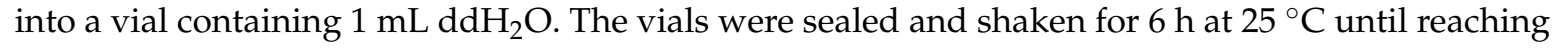
equilibrium. After centrifugation at $12,000 \times \mathrm{g}$ for $10 \mathrm{~min}$, the supernatant was filtered through a $0.22 \mu \mathrm{m}$ filter. The measured PPD solution $(0.1 \mathrm{~mL})$ was blended to $0.9 \mathrm{~mL}$ ginsenoside compound $\mathrm{K}$ or structure 1 filtrate well, respectively. The concentrations of ginsenoside compound $\mathrm{K}$ and structure 1 in the filtrate were determined by HPLC $\left(A c: \mathrm{H}_{2} \mathrm{O}=60: 40 ; \lambda=203 \mathrm{~nm}\right)$. Experiments were performed in triplicate.

\subsection{Formation of Foam Cells (Oil Red O Staining) [29]}

RAW264.7 cells were seeded in 24-well plates covered by glass slides at $1 \times 10^{5} / \mathrm{mL}$, and incubated with $100 \mu \mathrm{g} / \mathrm{mL}$ ox-LDL and different doses of tested structures for another $24 \mathrm{~h}$. The cells were treated with ox-LDL (ox-low density lipoprotein) and DMSO solution (1:1000) as the model group. The cells were gently washed with PBS (phosphate buffer saline) three times and fixed with $4 \%$ paraformaldehyde for $30 \mathrm{~min}$, and then subsequently stained with Oil Red $\mathrm{O}$ for $1 \mathrm{~h}$. The accumulated lipid droplets in the macrophages were visualized using a Nikon Eclipse 90i light microscope (Nikon Instruments, New York, NY, USA). Oil Red O stained cellular cholesteryl ester was extracted from the foam cells by isopropanol, and quantified by the optical density values at $500 \mathrm{~nm}$. The optical density values were calculated relative to the model group. The experiments were performed in octuplicate. 


\subsection{ABCA1 mRNA Expression in RAW264.7 [4]}

RAW264.7 cells were seeded in 12 -well plates at $1 \times 106 \mathrm{~mL}$, then treated with a final concentration $10 \mu \mathrm{M}$ of the tested structures for $24 \mathrm{~h}$ after cell adherence. Total RNAs were extracted with RNA simple Total RNA Kit, and the cDNA was synthesized with the Prime Script ${ }^{\mathrm{TM}}$ RT reagent Kit with gDNA Eraser. Real-time PCR was performed using SYBR ${ }^{\circledR}$ Premix Ex Taq ${ }^{\mathrm{TM}}$ II on a REALPLEX real-time PCR reaction system under the following conditions: $30 \mathrm{~s}$ at $95^{\circ} \mathrm{C}, 40$ cycles at $95{ }^{\circ} \mathrm{C}$ for $5 \mathrm{~s}$ and $60^{\circ} \mathrm{C}$ for $30 \mathrm{~s}$. Primers for mouse $\beta$-actin were $5^{\prime}$-ATTGAACATGGCATTGTTACC- $3^{\prime}$ and $5^{\prime}$-GGCATACAGGGACAGCACAGC- ${ }^{\prime}$; for mouse ABCA1 were $5^{\prime}$-ACATCCTCGTCCATTAAGCC- $3^{\prime}$ and $5^{\prime}$-AACTCTGGCACACTCATTGC- $3^{\prime}$. The fold increase relative to control samples was determined by the $2-\Delta \Delta \mathrm{Ct}$ (cycle threshold) method, and the $\mathrm{Ct}$ values were normalized to the expression levels of $\beta$-actin. Experiments were performed in quintuplicate.

\subsection{Cellular Toxicity}

Cellular toxicity assays were carried out by the CCK-8 method [30] on RAW264.7 and HUVEC cells. Cells were seeded in 96-well plates at $3 \times 10^{4} / \mathrm{mL}$ per well in RPMI- 1640 containing $10 \%$ fetal bovine serum, then treated with different concentrations $(10,30$ and $100 \mu \mathrm{M})$ of the tested structures for another $24 \mathrm{~h}$ after cell adherence. Meanwhile, one group of cells was given DMSO (1\%) as vehicle control. CCK-8 reagents $(10 \mu \mathrm{L} /$ well $)$ were added into the wells. Cells were incubated $37^{\circ} \mathrm{C}$ for $1 \mathrm{~h}$, and the optical density values were measured at $450 \mathrm{~nm}$ by the microplate reader. The survival rates of the treated cells were calculated relative to the control group. Experiments were performed in triplicate.

\subsection{Luciferase Reporter Assay}

HEK293 cells, with $1 \times 10^{5}$ cells/well in 96-well plates, were transfected with hLXREx3TK-Luc

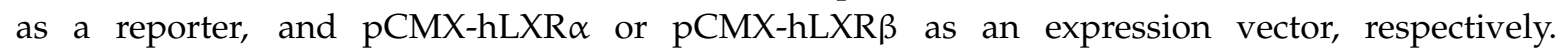
pSV- $\beta$-galactosidase was used to normalize the transfection efficiencies. The plasmids were transfected into the cells with Lipofectamine 3000 Reagent (Thermo Fisher Scientific, Waltham, MA, USA). After $24 \mathrm{~h}$ incubation, cells were treated with compound $\mathrm{K}$ derivatives $(10 \mu \mathrm{M})$, or vehicle (1\%o DMSO) for $24 \mathrm{~h}$. GW3965 $(10 \mu \mathrm{M})$ was used as a positive control. Then the cells were lysed, and the luciferase and $\beta$-galactosidase activities were detected by Varioskan LUX (Thermo Fisher Scientific, Waltham, MA, USA). The results were presented as relative luciferase activity.

\section{Conclusions}

In conclusion, a new class of ginsenoside compound $\mathrm{K}$ derivatives was synthesized and evaluated regarding the activation of $L X R \alpha$. All of the structures of this novel class of ginsenoside compound $\mathrm{K}$ derivatives were able to enhance the activation of $\mathrm{LXR} \alpha$. Especially structure $\mathbf{1}$ and structure $\mathbf{2}$ were identified as highly potent (cholesteryl ester contents: $41.51 \%$ and $37.74 \%$ ) and as having low cytotoxicity. Further experiments proved that structures 1, 2 and 4 obviously promoted ABCA1 mRNA expression (expression of ABCA1 mRNA: 319\%, 278\% and 259\%) via LXR $\alpha$ activity evaluation, and sequentially increased the level of reverse cholesterol transport. Among all the investigated structures, structure 1 exhibited the best potency (cholesteryl ester contents: $41.51 \%$; expression of ABCA1 mRNA: 319\%) and low cytotoxicity, this result provides a foundation for further modification of compound K research.

Supplementary Materials: The supplementary materials are available online.

Acknowledgments: This work was supported by the National Natural Science Foundations of China (No. 81102448 and 81673427) and Chongqing Research Program of Basic Research and Frontier Technology (No. cstc2015jcyjBX0093).

Author Contributions: Yi Jia and Xiaohui Li conceived and designed the experiments; Yan Huang performed the chemistry and molecular modeling experiments; Hongmei Liu performed the cell experiments; Yingxian Zhang 
performed the luciferase reporter assay experiments; Jin Li and Chenping Wang performed water solubility experiments; Li Zhou contributed analysis tools; Yi Jia and Yan Huang wrote the paper.

Conflicts of Interest: The authors declare no conflict of interest.

\section{References}

1. Logue, J.; Murray, H.M. Obesity is associated with fatal coronary heart disease independently of traditional risk factors and deprivation. Heart 2011, 97, 564-568. [CrossRef] [PubMed]

2. Fruchart, J.C.; Sacks, F.M. The Residual risk reduction initiative: A call to action to reduce residual vascular risk in dyslipidaemic patient. Diabetes Vasc. Dis. Res. 2008, 5, 319-335. [CrossRef] [PubMed]

3. Zhang, Y.G.; Zhang, H.G. Panaxnotoginsengsaponins attenuate atherosclerosis in rats by regulating the blood lipid profile and an anti-inflammatory action. Clin. Exp. Pharmacol. Physiol. 2008, 35, 1238-1244. [CrossRef] [PubMed]

4. Jia, Y.; Li, Z.Y. Panaxnotoginsengsaponins decrease cholesterol ester via up-regulating ATP-binding cassette transporter A1 in foam cells. J. Ethnopharmacol. 2010, 132, 297-302. [CrossRef] [PubMed]

5. Maqdasy, S.; Trousson, A. Once and for all, $\mathrm{LXR} \alpha$ and $\mathrm{LXR} \beta$ are gatekeepers of the endocrine system. Mol. Asp. Med. 2016, 49, 31-46. [CrossRef] [PubMed]

6. Kim, H.K. Pharmacokinetics of ginsenoside Rb1 and its metabolite compound K after oral administration of Korean Red Ginseng extract. J. Ginseng Res. 2013, 37, 451-456. [CrossRef] [PubMed]

7. Hu, C.; Song, G. Intestinal metabolite compound $\mathrm{K}$ of panaxoside inhibits the growth of gastric carcinoma by augmenting apoptosis via bid-mediated mitochondrial pathway. J. Cell. Mol. Med. 2012, 16, 96-106. [CrossRef] [PubMed]

8. Zheng, Z.Z.; Ming, Y.L. Compound K-induced apoptosis of human hepatocellular carcinoma MHCC97-H cells in vitro. Oncol. Rep. 2014, 32, 325-331. [CrossRef] [PubMed]

9. Park, E.S.; Lee, K.P. Compound K, an intestinal metabolite of ginsenosides, inhibits PDGF-BB-induced VSMC proliferation and migration through G1 arrest and attenuates neointimal hyperplasia after arterial injury. Atherosclerosis 2013, 228, 53-60. [CrossRef]

10. Yang, C.S.; Ko, S.R. The ginsenoside metabolite compound K, a novel agonist of glucocorticoid receptor, induces tolerance to endotoxin-induced lethal shock. J. Cell. Mol. Med. 2008, 12, 1739-1753. [CrossRef] [PubMed]

11. Chen, J.; Wang, Q. The ginsenoside metabolite compound $\mathrm{K}$ exerts its anti-inflammatory activity by downregulating memory B cell in adjuvant-induced arthritis. Pharm. Biol. 2016, 54, 1280-1288. [CrossRef] [PubMed]

12. Zhou, L.; Zheng, Y. Compound K attenuates the development of atherosclerosis in ApoE-/ - mice via LXR $\alpha$ activation. Int. J. Mol. Sci. 2016, 17, 1054. [CrossRef] [PubMed]

13. Joseph, S.B.; Laffitte, B.A. Direct and indirect mechanisms for regulation of fatty acid synthase gene expression by liver X receptors. J. Biol. Chem. 2002, 277, 11019-11025. [CrossRef] [PubMed]

14. Bełtowski, J. Liver $X$ receptors (LXR) as therapeutic targets in dyslipidemia. Cardiovasc. Ther. 2008, 26, 297-316. [CrossRef] [PubMed]

15. Zhang, Y.; Tong, D. Ascorbylpalmitate/D- $\alpha$-tocopheryl polyethylene glycol 1000 succinate monoester mixed micelles for prolonged circulation and targeted delivery of compound $\mathrm{K}$ for antilung cancer therapy in vitro and in vivo. Int. J. Nanomed. 2017, 12, 605-614. [CrossRef] [PubMed]

16. Svensson, S.; Ostberg, T. Crystal structure of the heterodimeric complex of LXRalpha and RXRbeta ligand-binding domains in a fully agonistic conformation. EMBO J. 2003, 22, 4625-4633. [CrossRef] [PubMed]

17. Sparrow, C.P.; Baffic, J. A potent synthetic LXR agonist is more effective than cholesterol loading at inducing ABCA1 mRNA and stimulating cholesterol efflux. J. Biol. Chem. 2002, 277, 10021-10027. [CrossRef] [PubMed]

18. Joseph, S.B.; McKilligin, E. Synthetic LXR ligand inhibits the development of atherosclerosis in mice. Proc. Natl. Acad. Sci. USA 2002, 99, 7604-7609. [CrossRef] [PubMed]

19. Calpe-Berdiel, L.; Rotllan, N. Liver X receptor-mediated activation of reverse cholesterol transport from macrophages to feces in vivo requires ABCG5/G8. J. Lipid Res. 2008, 49, 1904-1911. [CrossRef] [PubMed]

20. Gilbert, M.R. Natural Products as a Robust Source of New Drugs and Drug Leads: Past Successes and Present Day Issues. Am. J. Cardiol. 2008, 101, 43D-49D. 
21. Ryu, S.K.; King, T.J. Effect of an oral astaxanthinprodrug (CDX-085) on lipoprotein levels and progression of atherosclerosis in LDLR-/ - and ApoE-/ - mice. Atherosclerosis 2012, 222, 99-105. [CrossRef] [PubMed]

22. Lau, K.S.; Partridge, E.A. Complex N-Glycan Number and Degree of Branching Cooperate to Regulate Cell Proliferation and Differentiation. Cell 2007, 129, 123-134. [CrossRef] [PubMed]

23. Campbell, C.T.; Aich, U. Targeting Pro-Invasive Oncogenes with Short Chain Fatty Acid-Hexosamine Analogues Inhibits the Mobility of Metastatic MDA-MB-231 Breast Cancer Cells. J. Med. Chem. 2008, 51, 8135-8147. [CrossRef] [PubMed]

24. Elmouelhi, N.; Aich, U. The Hexosamine Template-A Platform for Modulating Gene Expression and for Sugar-based Drug Discovery. J. Med. Chem. 2009, 52, 2515-2530. [CrossRef] [PubMed]

25. Naoshima, Y.; Daijro, H. Synthesis of Both Enantiomers of 6-Methyl-3-octanone, An Alarm Pheromone of Ants of the Genus Crematogaster. Agric. Biol. Chem. 1988, 52, 1605-1606. [CrossRef]

26. Liu, J.H.; Chen, D. Discovery, synthesis, and structure activity relationships of 20(S)-protopanaxadiol (PPD) derivatives as a novel class of AMPK $\alpha 2 \beta 1 \gamma 1$ activators. Eur. J. Med. Chem. 2014, 79, 340-349. [CrossRef] [PubMed]

27. Lou, Q.H.; Meng, X. Design, Synthesis and Antifibrotic Activities of Carbohydrate-Modified 1-(Substituted aryl)-5-trifluoromethyl-2(1H) Pyridones. Molecules 2012, 17, 884-896. [CrossRef] [PubMed]

28. Zeng, K.; Thompson, K.E. Synthesis and biological evaluation of quinic acid derivatives as anti-inflammatory agents. Bioorg. Med. Chem. Lett. 2009, 19, 5458-5460. [CrossRef] [PubMed]

29. Fan, J.S.; Liu, D.N. Panax notoginseng saponins attenuate atherosclerosis via reciprocal regulation of lipid metabolism and inflammation by inducing liver $X$ receptor alpha expression. J. Ethnopharmacol. 2012, 142, 732-738. [CrossRef] [PubMed]

30. Wang, Y.Q.; Xu, M.D. BCL6 is a negative prognostic factor and exhibits pro-oncogenic activity in ovarian cancer. Am. J. Cancer Res. 2014, 5, 255-266. [PubMed]

Sample Availability: Samples of the compounds are available from the authors.

(C) 2017 by the authors. Licensee MDPI, Basel, Switzerland. This article is an open access article distributed under the terms and conditions of the Creative Commons Attribution (CC BY) license (http://creativecommons.org/licenses/by/4.0/). 